\title{
LIGNIN CONTENT IN FERMENTATION OF COCOA POD (THEOBROMA COCOA) USED PLEUROTUS OSTREATUS
}

\author{
Engkus Ainul Yakin ${ }^{1 *}$, Sri Sukaryani ${ }^{2)}$ and Abbas Ummami ${ }^{3)}$ \\ ${ }^{1,2,3)}$ Program Study of Animal Science, Faculty of Agriculture, \\ Universitas Veteran Bangun Nusantara, Sukoharjo \\ J1. Letjen. Sujono Humardani No. 1, Sukoharjo \\ *Coresponding Author. Email : engkus_ainul@yahoo.com
}

\begin{abstract}
The study were aimed to determine the lignin degradation in fermentation of cocoa pod with Pleurotus ostreatus. The research methods was using three treatments and four replications. $\mathrm{T} 0=$ fermentation of cocoa pod in 10 days, $\mathrm{T} 1=$ fermentation of cocoa pod in 15 days, and $\mathrm{T} 2$ = fermentation of cocoa pod in 20 days. The mixture was put into a container aerobically. The variables observed were dry matter (DM), crude protein (CP), crude fiber (CF), crude fat (CFt), ash and lignin content. This study was designed using the completely randomized research design with a unidirectional pattern analysis of variance (oneway ANOVA). Significant variables went through Duncan's Multiple Range Test (DMRT). The result showed that thelower lignin content was T2 = fermentation of cocoa pod in 20 days $=6.40 \pm 0.12 \%$. It could be concluded that the addition of fungus Pleurotus ostreatus on cocoa pod fermented during 20 days was the lower lignin content in fermentation of cocoa pod.
\end{abstract}

Keywords : Cocoa pod, Fermentation, Lignin, Pleurotus ostreatus.

\section{INTRODUCTION}

Waste food crops and plantations have an important role and potential in the supply of green feed for ruminants such as cattle, goats, sheep and buffalo, especially in the dry season (Yakin et al., 2017). The main barriers to livestock farmers, especially in the livestock population increase is limited feed. The expansion of areas for planting grass as ruminant feed is very difficult, because the land use is very high. Considering the inadequacy of grazing land, then any efforts to re-use agricultural waste as the farm feed need to be combined with other materials that until now have not been commonly used as feed.
The waste of crops and plantation has an important role and high potential in providing forage for ruminants such as cattle, goats, sheep and buffalo, especially in the dry season. In the dry season forage grasses are stunted, resulting in less available forage in terms of both quantity and quality. Even in certain areas fodder grass will dry up and die, causing a crisis of forage. In addition, ruminants maintenance system is still largely dependent on the form of forage grasses and other forage with little or no additional feed. 
Cocoa pod has an important role and potential in ruminant feed supply, especially for goats, more over during the dry season. Utilization of cocoa pod as animal feed can be given in the form of raw material or in the form of flour after being processed. Research findings showed that the fresh cocoa pod with sun-dried and then milled can be used as animal feed.

Cocoa pod is an agro industrial waste produced by cocoa plant (Theobroma cacao L.). Cocoa fruit has result of cocoa pod about $74 \%$, cocoa bean about $2 \%$ and $24 \%$ fruit flacent. The proximate analysis results showed that it contains $88.98 \%$ dry matter (DM), $79.89 \%$ organic matter $(\mathrm{OM})$, 9.14 crude protein (CP), 35.74\% crude fiber (CF) (Alemawor et al., 2009). Another expert stated nutritional content of cocoa pod consists of DM 91.80\%, BO $88.90 \%$, CP $6.20 \%$, and $\mathrm{CF} 45.90 \%$ and $50.8 \%$ (Aregheore, 2002). Lateef et al. (2008) report that content of cocoa pod consist $\mathrm{BO} 88.70 \%$, CP $8.20 \%$, CFt 4.70 and CF $18.30 \%$. Suparjo et al. (2009) report that content of cocoa pod consist DM $48.17 \%$ and BO 93.93\%.

Fungi degrade lignin are most active white-rot fungi, such as Pleurotus ostreatus and Coriolus versi color able to hemicellulose, cellulose and lignin from plant waste into $\mathrm{CO}_{2}$ and $\mathrm{H}_{2} \mathrm{O}$ (Paul, 1992; Limura, 1996). In general, whiterot basidiomisetes synthesize three kinds of enzymes, Lignin-peroxidase (LiP), manganese-peroxidase (MnP) and laccase. The all of these enzyme plays an important role in the degradation of lignin (Srinivasan et al., 1995).

From the results of research conducted on sheep, that the use of cocoa pod can be used as a substitute supplement as much as $15 \%$ or $5 \%$ of the ration. Preferably before used as animal feed, cocoa pod waste needs to be fermented prior to degrade the indigestible lignin content consumed by animals and to increase the protein content of $6-8 \%$ to $12-15 \%$.

The specific objective to be achieved in this research was to examine the nutrient content and a decrease in lignin content in fermented of cocoa pod. It was expected that this research would produce a proper referential method in the processing of agricultural cocoa pod waste using the services of molds so that they can be used for further studies when given to ruminants.

\section{MATERIALS AND METHODS}

\section{Materials}

Pleurotus ostreatus was maintained at $37^{\circ} \mathrm{C}$ on potato dextrose agar (PDA) (200 $\mathrm{gL}^{-1}$ potato extract, $20 \mathrm{gL}^{-1}$ glucose and $20 \mathrm{gL}^{-1}$ agar) plates. Pleurotus ostreatus was cultured in animmersed liquid culture system.

\section{Cocoa pod}

Fresh cocoa pods are collected from the people's plantations in Selorejo Village, Girimarto District, Wonogiri Regency. The cocoa pod then chopped and cut into sizes of $1-3 \mathrm{~cm}$ and dried in the sun to $35 \%$ water content (Yakin et al., 2020).

\section{Methodology \\ Solid state fermentation}

The solid state fermentation was conducted in a $250 \mathrm{~mL}$ Erlenmeyer flask as the fermenter. Erlenmeyer flask was filled with $50 \mathrm{~g}$ of cocoa pod, which was then inoculated with mold as much as $5 \%$ of the weight of the 
substrate based on the dry matter. The fermentation process used a shaker incubator at a speed of $150 \mathrm{rpm}$ and temperature of $30^{\circ} \mathrm{C}$. Before and after fermentation, cocoa pod were weighted. At the end of fermentation, cocoa pod was dried at $50^{\circ} \mathrm{C}$ for 4 days to stop the activity of microorganisms. Cocoa pod was milled and shieved using a Thomas-Wiley Mill type 4 with a diameter of $1 \mathrm{~mm}$ sieve. The research design used a completely randomized design with five treatments and six replications. The treatments were $\mathrm{T} 0=$ fermentation of cocoa pod in 10 days, $\mathrm{T} 1=$ fermentation of cocoa pod in 15 days, and $\mathrm{T} 2=$ fermentation of cocoa pod in 20 days.

\section{Statistical analysis}

Data were analyzed with analysis of variance analysis (ANOVA) and a unidirectional pattern followed by Duncan's Multiple Range Test Test
(DMRT) (Christensen, 1996) in case there was any difference.

\section{Research Procedures}

The fermentation was carried out in aerobic fermentation on cocoa pod fermentation treatment. Fresh cocoa pod was chopped and dried. $100 \mathrm{~g}$ of cocoa pod with water content of $61.23 \%$ was placed on a plastic container inoculated with Pleurotus ostreatus and mixed thoroughly. Cocoa pod before and after fermentation were examined for the nutrient and lignin content analysis by using proximate analysis (AOAC, 2005). Parameters observed were Dry Matter (DM), Crude Protein (CP), Crude Fiber(CF), Crude Fat $(\mathrm{CFt})$, Ash and lignin.

\section{RESULT AND DISCUSSION}

The results of the proximate analysis and calculation of lignin fermentation of cocoa pod using Pleurotus ostreatus that have been implemented are listed in the table.

Average of chemical composition of cocoa pod fermented using Pleurotus ostreatus (\% DM)

\begin{tabular}{lccc}
\hline \multirow{2}{*}{ Variable } & \multicolumn{3}{c}{ Matterial $(\%)$} \\
\cline { 2 - 4 } & $\mathrm{T} 0$ & $\mathrm{~T} 1$ & $\mathrm{~T} 2$ \\
\hline Lignin & $8.05^{\mathrm{c}} \pm 0.19$ & $7.41^{\mathrm{b}} \pm 0.23$ & $6.40^{\mathrm{a}} \pm 0.12$ \\
Dry Matter & $77.52^{\mathrm{a}} \pm 0.42$ & $81.42^{\mathrm{ab}} \pm 0.09$ & $84.35^{\mathrm{b}} \pm 5.16$ \\
Crude Protein & $2.11^{\mathrm{a}} \pm 0.06$ & $2.44^{\mathrm{b}} \pm 0.21$ & $1.94^{\mathrm{a}} \pm 0.11$ \\
Crude Fiber & $11.72^{\mathrm{c}} \pm 0.19$ & $9.65^{\mathrm{b}} \pm 0.28$ & $8.47^{\mathrm{a}} \pm 0.32$ \\
Crude Fat & - & - & - \\
Ash & $2.76^{\mathrm{b}} \pm 0.05$ & $2.75^{\mathrm{b}} \pm 0.17$ & $2.32^{\mathrm{a}} \pm 0.13$ \\
\hline Superscript different on the same line indicate a very significant $(\mathrm{P}<0.01) . \mathrm{T} 0=$ fermented cocoa pod \\
$\quad$ for 10 days, T1 = fermented cocoa pod for 15 days, T2 = fermented cocoa pod for 20 days.
\end{tabular}

Lignin

The mean of the chemical composition of lignin are listed in table.
The mean of the three consecutive treatments were $\mathrm{T} 0=8.05 \pm 0.19 \%, \mathrm{~T} 1$ $=7.41 \pm 0.23 \%$, and $\mathrm{T} 2=6.40 \pm 0.12 \%$. 
It showed highly significant results $(\mathrm{P}<0.01)$.

The fermentation using Pleurotus ostreatus showed that fermentation for 20 days was a treatment with the lower lignin content which was $6.40 \pm 0.12 \%$. This happenned because the lignin contained in the cocoa pod is high and there should be a special treatment to reduce the lignin content. With the longer days of fermentation it was seen that the reduction in lignin content also decreased.

The decrease of lignin on cocoa pod fermentation with this fungus is due to the lignin degradation process that run optimally resulting in decrease levels of lignin (Yakin et al., (2017). Pleurotus ostreatus can effectively degrade lignin by producing extracellular peroxidase enzymes namely lignin perxsidase and mangan peroxidase (Yakin et al., 2020). Lignin peroxidase and $\mathrm{MnP}$ has the same degradation mechanism on lignin. Lignin peroxidase is a peroxidase enzyme and $\mathrm{MnP}$ extracellular using $\mathrm{H}_{2} \mathrm{O}_{2}$ to degrade lignin. While laccase is an enzyme containing copper using molecular oxygen to degrade lignin (Hattaka, 1994).

\section{Dry Matter}

The mean of the chemical composition of water are listed in table. The mean of the three consecutive treatments were $\mathrm{T} 0=77.52 \pm 0.42 \%, \mathrm{~T} 1=$ $81.42 \pm 0.09 \%$, and $\mathrm{T} 2=84.35 \pm 5.16 \%$. It showed highly significant results $(\mathrm{P}<0.01)$.

The fermentation using Pleurotus ostreatus showed that fermentation for 20 days is the treatment with the highest water content which was $84.35 \pm 5.16 \%$. This is due to the activity of microbes in the fermentation activity in the cocoa pod can produce $\mathrm{CO}_{2}$ resulting in increasing water content.
According to (Suparjo et al., 2009) stated that the decrease in DM cocoa pod which was fermented by using Phanerochaete chrysosporium for 5 days was $5.52 \%$. This is due to the addition of Manganese $(\mathrm{Mg})$ mineral to the cocoa pod substrate. The function of this mineral can increase the growth rate and extend the mold mycelium, with the addition of this mineral, the use of DM is more efficient. Cocoa pod fermentation process, one of which isi determined by addtion of microbes such as bacteria or fungi that can accelerate the fermentation process (Hanim et al., 2010).

\section{Crude Protein}

The mean of the chemical composition of the proteins are listed in table. The mean of the three consecutive treatments were $\mathrm{T} 0=2.11$ $\pm 0.06 \%, \mathrm{~T} 1=2.44 \pm 0.21 \%$, and $\mathrm{T} 2=$ $1.94 \pm 0.11 \%$. It showed highly significant results $(\mathrm{P}<0.01)$.

The fermentation using Pleurotus ostreatus showed that fermentation for 10 and 20 days showed better protein value compared to the fermentation for 15 days. Laconi (1998) reported that cocoa pod fermented using Phanerochaete chrysosporium fungi which added molasses $3 \%$ of the weight of the media is by changing towards an increase in crude protein content of $20.72 \%$. While (Sutikno et al., 1994) reported that fermented cocoa pod using Aspergillus niger with the addition of urea and minerals significantly affected the increase in $\mathrm{CP}$ content from $5.88 \%$ to $10.73 \%$ in 4 days fermentation or an increase of $47.91 \%$.

This is due to the activity of microbes in the fermentation activity in 
the cocoa pod are expected to increase the protein content not as expected. Although it seemed to be different but the proteins that were produced from the fermentation of the cocoa pod was still relatively very low in protein content increase. Therefore if we want it to be used as ruminant rations it needs to be added with certain feed ingredients which can raise the protein content of feed.

One of the important nutritional elements of feed ingredients is protein. Purwadaria et al., (2003) stated that in the fermentation process of feed ingredient using Aspergillus niger, there is due to the growth of mycelium, loss of dry matter, phytase enzyme production and the presence of the protease enzyme hydrolysis process.

\section{Crude Fiber}

The mean of the chemical composition of crude fiber are listed in table. The mean of the three consecutive treatments were $\mathrm{T} 0=11.72 \pm 0.19 \%, \mathrm{~T} 1=$ $9.65 \pm 0.28 \%$, and $\mathrm{T} 2=8.47 \pm 0.32 \%$. It showed highly significant results $(\mathrm{P}<0.01)$.

The fermentation using Pleurotus ostreatus showed that fermentation for 20 days was the lowest crude fiber content which was $8.47 \pm 0.32 \%$. Decrease levels of crude fiber are caused by the activity of the enzymes produce by fungi so that the activity of the enzyme is able to degrade the fiber fraction so that the bond that was strong became tenuous (Alemawor et al., 2009). Alemawor et al. (2009) reported that there was a decrease in the content of cocoa pod by $7.64 \%$ using Aspergillus spp and added glucanase and xylanase enzymes. According to (Smith, 2002) that the urea solution serves to stretch or describe the lignohemicelulose and lignocellulose bonds in agricultural waste. Laconi et al., (1998) study found that there was a decrease of
$18.16 \%$ in the content of crude fiber of cocoa pod by using Phanerochaete chrysosporium mold, 5-7 $\mathrm{mm}$ cocoa pod chopped particles and 3\% molasses added from the total media.

This was due to the microbial activity in the activity in the fermentation proces of cocoa pod. This suggests that the addition of microbial Pleurotus ostreatus the fermentation process of cocoa pod can lower crude fiber content in the cocoa pod, so that when used as animal feed it can be more efficient in the process of digestion.

\section{Crude Fat}

The results of the proximate analysis that has been carried out to determine the crude fat content contained in the cocoa pod with cocoa fermentation for 10,15 and 20 days were not able to show the number or not detected because the fat content was very small. Fat has the main function as a backup energy in the form of triglycerides (Toha et al., 2005). According to (Hamid et al., 1999) that the lipase enzyme in Pleurotus ostreatus has a role in hydrolyzing fat into glycerol and fatty acids in the presence of water molecules. This mold activity has caused a decrease in the content of the cocoa pod crude fat in fermentation using Pleurotus ostreatus.

\section{Ash}

The mean of the chemical composition of the ash are listed in table. The mean of the three consecutive treatments were $\mathrm{T} 0=2.76$ $\pm 0.05 \%, \mathrm{~T} 1=2.75 \pm 0.17 \%$, and $\mathrm{T} 2=$ $2.32 \pm 0.13 \%$. It showed highly significant results $(\mathrm{P}<0.01)$. 


\begin{abstract}
The fermentation using Phanerochaete chrysosporyum 20 days was the treatment with the lowest ash content of $2.75 \pm 0.17 \%$. This was due to the microbial activity in the activity in the

fermentation process of cocoa pod. This suggests that the addition of Pleurotus ostreatus in the fermentation process of cocoa pod can reduce the ash content of the cocoa pod.
\end{abstract}

\title{
CONCLUSION
}

It could be concluded that the addition of fungus Pleurotus ostreatus on cocoa pod fermented during 20 days was the lower lignin content in fermentation of cocoa pod.

\section{REFERENCES}

Alemawor, F., V.P. Dzogbefia, E.O.K. Oddoye and JJ.H. Oldham. 2009. Enzyme cocktail for enhancing poultry utilization of cocoa pod husk composition. Scientific Research and Essay.4 (6) : 555-559. Aregheore, E.M. 2002. Chemical evaluation and digestibility of cocoa (Theobroma cacoa) by product fed to goats. Trop. Anim. Health and Production. 34: 339348.

Association of Official Analytical Chemists.2005. Official Methods of Analysis. 15th Ed. Association of Official Analytical Chemist, Washington, DC., USA.

Christensen, R. 1996. Analysis of Variance, Design and Regession : Applied Statistical Methods. Chapman and Hall. London

Hamid, H., T. Purwadaria, T. Haryati dan P. Sinurat. 1999.Perubahan nilai bilangan peroksida bungkil kelapa dalam proses penyimpanan dan fermentasi dengan Aspergillus niger. JITV 4 : 101-106.

Hanim, C., L.M. Yusiati, and V.P. Budyastuti. 2010. In vitro gas production of fermented cocoa pod
Theobroma cacao added with cellulolytic inoculum from cattle rumen fluid. Proc. 5th international Seminar on Tropical Anim. Production. Part 1. Yogyakarta 1922 October 2010. Fac. of Anim. Sci. Univ. Gadjah Mada. pp. 171-176.

Hattaka, A. 1994. Modifying enzymes from selected white-rot fungi : production and role in lignin degradation. Microbiology. 13:125135.

Laconi, E.B. 1998. Peningkatan Mutu Pod Cacao Melalui Amoniasi dengan Urea dan Biofermentasi dengan Phanerochaete chrysosporium serta Penjabarannya ke dalam Formulasi Ransum Ruminansia. Disertasi. Program Pascasarjana Institut Pertanian Bogor, Bogor.

Lateef, A., Oloke, J.K., Kana, E.B.G., Oyeniyi, S.O., Onifade, O.R., Oyeleye, A.O., Oladosu, O.C., Oyelami, A.O. 2008. Improving the quality of agro-wastes by solidstate fermentation : Enhanced antioxidant activities and nutritional qualities. DIG World J. Microbiol. Biotechnol., DOI : 
10.1007/s11274-008-9749-8. 24: 2369-2374.

Limura, Y., P. Hartikainen, and K. Tatsumi. 1996 . Dechlorination of tetrachloroguaiacol by laccase of white rot basidiomycete Coriolus versicolor Appl. Microbiol. Biotechnol. 45 : 434-439

Paul. EA. 1992. Organic Matter Decompositionn. Encyclopedia of Microbiology. Vol.3. Academic Press. Inc.

Purwadaria, T., R. Irayati, A.P. Sinurat, and I.W.R. Susana. 2003. The activity of phitase and phphorus content of fermented dry palm oil mill effluent (POME) and rice bran with Aspergillus orizae GS-66. J. Biotechnologi Pertanian. 8 (2) : 4651.

Smith, T. 2002. On-farm treatment of straw and stover with urea. Proc. Of The Final Review Meeting of an IAEA Technical Co-Operation Regional AFRA Project. Cairo Egypt. 25-29 Nov 2000. Organized by FAO/IAEA Division of Nuclear Tecniques in Food and Agriculture. pp 15-22.

Srinivasan. C., T.M.D. Souza, K. Boominathan, and C.A. Reddy. 1995. Demonstration of Laccase in the White Rot Basidiomycete Phanerochaete chrysosporium. Aplied and Environmental Microbiology. 61 (2): 4274-4277.

Suparjo, Wiryawan, K.G., Laconi E.B., dan Mangunwidjaja, D. 2009. Perubahan komposisi kimia kulit buah kakao akibat penambahan mangan dan kalsium dalam biokonversi dengan kapang Phanerochaete chrysosporium. Media Peternakan. 32 (3): 203-210.
Sutikno, A.I., T. Haryati dan J. Darma. 1994. Perbaikan kualitas gizi pod coklat melalui proses fermantasi. Buku 2. Pros. Sem. Sains dan Teknologi Peternakan. Pengolahan dan dan Komunikasi Hasil-Hasil Penelitian, Ciawi-Bogor 25-26 Januari 1994. Balitnak, Puslitbangnak., Badan Litbangtan., Bogor. 753-76.

Toha, A.H.A. 2005. Biokimia : Metabolisme Biomolekul. Cetakan Kedua. Alfabeta, Bandung. pp 99121.

Yakin, E.A., Z. Bachruddin, R. Utomo, and R. Millati. 2017. Effect of Lignocellulolytic Fungus to Enzimatic Activity, Fiber Fraction and Digestibility on Fermentation Process of Cocoa Pod. Buletin of Animal Science. 41 (3) : 250-256.

Yakin, E.A., Z. Bachruddin, R. Utomo, and R. Millati. 2020. Application of cocoa pod fermentation used the $P$. chrysosporium with Addition of $\mathrm{Mn}^{2+}$ on performance of the Javanesse Thin Tailed sheep. Pakistan Journal of Nutrition. 19 (5) : 231-238 